\title{
HUBUNGAN BEBAN KERJA PERAWAT DENGAN PENERAPAN PRINSIP TUJUH BENAR DALAM PEMBERIAN OBAT PADA PASIEN DI RUANG RAWAT INAP
}

\author{
Ahsan $^{1}$, Linda Wieke Noviyanti ${ }^{2}$, Titis Sukma Primanoviasari ${ }^{3}$ \\ Program Studi IImu Keperawatan Fakultas Kedokteran Universitas Brawijaya \\ E-mail: ahsanfkub@yahoo.com
}

\begin{abstract}
Perception that the administration of seven drugs correctly making burden workload, so that nurses do nursing care activities in a hurry. Treatment errors are not only caused by nurses but also because patient themselves do not follow existing procedures. The purpose of this study was to identify the relationship between nurses' workload and the application of the seven principles of correctness in drug delivery to patients in the inpatient ward. This research is a correlational research with cross sectional design approach. The study was conducted on 26 March - 6 April 2018 in patient room B, C, D and E Wava Husada Kepanjen Hospital. The population of this study was the nurses, 46 nurses with proportional random sampling. Data collection were using questionnaires about nurses' workload and observation sheets about the application of the seven principles of drug administration. Data analysis was used Spearman Rank test and data presentation in the form of frequency distribution and narrative tables. The result Spearman Rank test it was found that there was a significant relationship between the workload of nurses and the application of the principle 7 correct drug administration. The workload of nurses should be properly regulated so as not to interfere with the application of the seven principles correctly in the administration of drugs to patients.
\end{abstract}

\section{Keywords : Nurse Workload, Principle Seven True Drug Giving}

\begin{abstract}
Abstrak : Persepsi bahwa pemberian obat tujuh benar menambah beban kerja, sehingga perawat dalam melakukan kegiatan asuhan keperawatan dengan terburu - buru. Kesalahan pengobatan bukan hanya ditimbulkan oleh perawat saja melainkan juga karena individu sendiri tidak mengikuti prosedur yang ada. Tujuan dari penelitian ini adalah mengidentifikasi adanya hubungan beban kerja perawat dengan penerapan prinsip tujuh benar dalam pemberian obat pada pasien di ruang rawat inap. Penelitian ini merupakan penelitian korelasional dengan dengan pendekatan cross sectional design. Penelitian dilakukan tanggal 26 Maret - 6 April 2018 di rawat inap B,C,D dan E Rumah sakit Wava Husada Kepanjen. Populasi penelitian ini adalah perawat pelaksana yang berjumlah 46 perawat dengan tehnik pengambilan sampel yaitu Proportional Random Sampling. Instrumen pengumpulan data adalah kuesioner tentang beban kerja perawat dan lembar observasi tentang penerapan prinsip tujuh benar pemberian obat. Analisa data menggunakan uji Spearman Rank dan penyajian data dalam bentuk tabel distribusi frekuensi dan narasi. Dari uji Spearman Rank didapatkan bahwa ada hubungan signifikan antara beban kerja perawat dengan penerapan prinsip tujuh benar pemberian obat. Beban kerja perawat sebaiknya diatur dengan baik supaya tidak mengganggu dalam penerapan prinsip tujuh benar dalam pemberian obat pada pasien.
\end{abstract}

Kata Kunci : Beban Kerja Perawat, Prinsip Tujuh Benar Pemberian Obat

\section{PENDAHULUAN}

Perawat adalah suatu profesi yang di mana pekerjaannya salalu berada dalam keaadaan yang harus berhubungan antar manusia dengan proses interaksi serta saling mempengaruhi satu sama lain serta memberikan dampak (Suhaemi, 2003). Perawat juga harus memberikan pengobatan kepada pasien yaitu dengan memberikan berbagai macam obat kepada pasien secara aman (Nursalam, 2011). Salah satu cara menjaga keamanan dalam hal pemberian obat di perlukan penerapan prinsip benar dalam pemberian obat. Tambayong (2001) mengemukakan prinsip enam benar yang meliputi benar pasien, benar obat, benar dosis, benar waktu dan benar dokumentasi. Dalam penelitian yang dilakukan oleh Abdar (2014) menyebutkan bahwa perawat memiliki peranan penting dalam mengurangi kejadian kesalahan pemberian obat,adapun faktor yang mempengaruhi kejadian kesalahan pemberian obat yaitu perbandingan antara pasien dan perawat tidak seimbang, jumlah perawat yang kurang memadai, burnout pada perawat saat bekerja, terjadi kesulitan dalam instruksi yang diberikan okeh dokter, beban kerja perawat yang terlalu berat, perawat yang bekerja saat bekerja pada shift malam, dan perawat kurang mengetahui tentang terapi obat. Perawat saat melakukan tindakan penerapan prinsip benar obat tidak dapat melakukan dengan baik dikarenakan beban kerja yang terlalu berlebih 
yang dapat menimbulkan kesalahan perawat, situasi lingkungan dan pengaturan ketenangan serta manajemen yang ada berkaitan dengan individu seseorang yang memiliki bemacammacam karakteristik yang ada seperti umur, jenis kelamin, pendidikan, status perkawinan, dan lama masa kerja yang dikemukakan oleh Gibson (llyas, 2002).

Munandar (2001) mengatakan bahwa beban kerja adalah suatu keadaan dari pekerjaan dengan uraian tugasnya yang harus diselesaikan pada batas waktu tertentu. Beban kerja adalah kemampuan tubuh pekerja dalam menerima pekerjaan. Hasil penelitian yang dilakukan oleh Sthepani (2015) mengatakan bahwa salah satu faktor dari penghambat pelaksanaan standar prosedur operasional tujuh benar dalam pemberian obat di ruang rawat inap disebabkan karena perawat mempunyai persepsi bahwa pemberian obat tujuh benar akan menambah beban kerja, sehingga perawat dalam melakukan asuhan keperawatan dengan terburu-buru.Kesalahan pengobatan bukan hanya ditimbulkan oleh perawat tapi juga karena individu tidak mengikuti prosedur yang ada.

Hasil studi pendahuluan yang dilakukan oleh peneliti di Rumah Sakit Wava Husada Kepanjen pada tanggal 31 januari 2018. Dilakukan dengan wawancara bersama kepala ruangan rawat inap $B, C, D$, dan $E$ didapatkan hasil bahwa jumlah pasien lebih banyak dari pada jumlah perawat yang bekerja di ruangan dan untuk jumlah pasien berkisar 30 orang sehingga banyak sekali perawat yang mengalami beban kerja. Setelah wawancara bersama kepala ruangan, peneliti melakukan wawancara dengan kepala rekam medis untuk melihat BOR (Bed Occupancy Ratio) atau penggunaan tempat tidur di ruangan, BOR tertinggi pada tahun 2017 di ruang rawat inap ada di ruang $B, C, D$, dan $E$ dengan rata-rata $88 \%$.

Berdasarkan uraian yang telah dijelaskan sebelumnya sangat dibutuhkan peran perawat dalam penerapan prinsip tujuh benar dalam pemberian obat terutama pada pasien di rawat inap karena keseluruhan perawatan medis bergantung oleh perawat. Perawat memberikan perawatan asuhan keperawatan secara penuh serta perbandingan jumlah antara perawat dan pasien tidak seimbang, sehingga mudah sekali perawat mengalami beban kerja. Jika perawat mengalami beban kerja berlebih maka akan berakibat dalam penerapan prinsip tujuh benar pemberian obat sehingga banyak sekali kejadian KTD (kejadian tidak diharapkan) yang terjadi di rawat inap.

\section{METODE PENELITIAN}

Penelitian ini menggunakan analisis korelasional dengan pendekatan cross sectional design. Populasi penelitian ini adalah perawat pelaksana di ruang rawat inap B,C,D dan E Rumah sakit Wava Husada Kepanjen yang berjumlah 46 perawat. Cara pengambilan sampel dengan teknik Proportional Random Sampling yaitu Pengambilan sampel secara proporsi dilakukan dengan mengambil subyek dari setiap wilayah ditentukan seimbang dengan banyaknya subyek dalam masingmasing strata atau wilayah.

Dengan menggunakan rumus besaran sampel, didapatkan jumlah sampel sebanyak 46 orang perawat. adapun besar atau jumlah pembagian sampel untuk masing-masing ruangan, menggunakan rumus alokasi proposional yaitu didapatkan jumlah sampel perawat di ruang rawat inap B sebesar 11 orang, rawat inap $C$ sebesar 11 orang, rawat inap $D$ sebesar 13 orang, dan rawat inap $E$ sebesar 11 orang.

Penelitian dilakukan di Rumah Sakit Wava Husada Kepanjen dilakukan pada tanggal 26 Maret - 6 April 2018 di ruang rawat inap B,C,D, dan E. Pengambilan data beban kerja menggunakan kuesioner dan untuk penerapan prinsip tujuh benar dalam pemberian obat peneliti mengobservasi secara langsung. Peneliti memberikan kuesioner kepada responden (perawat) yang bekerja di ruang rawat inap Rumah sakit Wava Husada Kepanjen yang sebelumnya sudah berkoordinasi dengan pihak kepala ruangan. Peneliti membagikan kuesioner kepada responden (perawat) untuk diisi dan sebelumnya peneliti memberikan informed consent kepada responden, setelah kuesioner terisi kemudian peneliti melakukan observasi secara langsung dengan membawa lembar observasi yang akan diisi oleh peneliti tentang penerapan prinsip tujuh benar.

Pemberian obat pada pasien di ruang rawat inap, yang sebelumnya peneliti telah mengetahui prinsip tujuh benar pemberian obat dari pihak kepala ruangan rawat inap rumah sakit sehingga dapat dimudahkan untuk observasi penerapan prinsip tujuh benar dalam pemberian obat. Data dianalisis dengan menggunakan uji Rank Spearman. Data hasil penelitian disajikan dalam bentuk tabel distribusi frekuensi dan narasi. 


\section{HASIL PENELITIAN}

Karakteristik Responden

Tabel 1. Karakteristik Responden Berdasarkan Usia

\begin{tabular}{ccc}
\hline Karakteristik & $\mathbf{n}$ & Mean $\pm \mathbf{s d}$ \\
\hline Usia & 46 & $26.543 \pm 3,118$
\end{tabular}

Berdasarkan hasil karakteristik usia responden di Rumah Sakit Wava Husada Kepanjen di Ruang B,C,D dan E padadan E pada tabel 1 bahwa perawat rata - rata berusia 26,543 Tahun. Usia memiliki standar deviasi sebesar 3,118 sehingga dapat diperkirakan bahwa data tertinggi pada usia 30 tahun dan terendah 24 tahun.

Tabel 2. Karakteristik Responden Berdasarkan masa kerja perawat

\begin{tabular}{ccc}
\hline Karakteristik & n & Mean $\mathbf{\text { sd }}$ \\
\hline Lama Masa Kerja & 46 & $24.61 \pm 25.047$ \\
\hline
\end{tabular}

Berdasarkan hasil karakteristik lama masa kerja responden di Rumah Sakit Wava Husada Kepanjen di Ruang B, C, D dan E pada tabel 3 bahwa lama masa kerja perawat rerata 24,61 Bulan. Lama masa kerja memiliki standar deviasi sebesar 25,047 sehingga dapat diperkirakan bahwa lama masa kerja tertinggi 96 bulan atau 8 tahun dan terendah lama masa kerja 1 bulan.

Tabel 3. Karakteristik Responden

\begin{tabular}{ccccc}
\hline Karakteristik & Kategori & Frekuensi & Persentase (\%) \\
\hline Jenis Kelamin & & Perempuan & 34 & 73.91 \\
& & Laki-laki & 12 & 26.09 \\
& Total & & 46 & 100 \\
\hline Pendidikan Terakhir & & Ners & 20 & 43.48 \\
& & D3 & 26 & 56.52 \\
& Total & & 46 & 100 \\
\hline \multirow{2}{*}{ Status Pernikahan } & & Belum Menikah & 23 & 50.00 \\
& & Sudah Menikah & 23 & 50.00 \\
& Total & & 46 & 100 \\
\hline
\end{tabular}

Data Hasil Beban Kerja

Tabel 4. Distribusi Frekuesi Beban Kerja

\begin{tabular}{ccc}
\hline & \multicolumn{2}{c}{ Beban Kerja } \\
\cline { 2 - 3 } Kategori & Jumlah (f) & Presentase \\
\hline Ringan & 14 & 30.43 \\
Sedang & 28 & 60.87 \\
Berat & 4 & 8.70 \\
\hline Total & 46 & 100 \\
\hline
\end{tabular}

Berdasarkan tabel 4 menunjukkan dari 46 perawat di ruang rawat inap B,C,D dan E Rumah Sakit Wava Husada Kepanjen, sebagian besar perawat memiliki beban kerja sedang sebanyak 28 orang $(60,87 \%)$ dan sebagian kecil perawat memiliki beban kerja berat sebanyak 4 orang $(8,70 \%)$. 
Data Hasil Penerapan Prinsip Tujuh Benar Pemberian Obat

Tabel 5. Distribusi Frekuensi Penerapan Prinsip Tujuh Benar Pemberian Obat

\begin{tabular}{ccc}
\hline \multirow{2}{*}{ Kategori } & \multicolumn{3}{c}{ Beban Kerja } \\
\cline { 2 - 3 } & Jumlah (f) & Presentase \\
\hline Kurang Patuh & 4 & 8.70 \\
Cukup Patuh & 16 & 34.78 \\
Patuh & 26 & 56.52 \\
\hline Total & 46 & 100 \\
\hline
\end{tabular}

Berdasarkan tabel 5 menunjukkan dari 46 perawat di ruang rawat inap B,C,D dan E Rumah Sakit Wava Husada Kepanjen, sebagian besar perawat patuh dalam penerapan prinsip 7 benar dalam pemberian obat sebanyak 26 orang $(56,52 \%)$, dan sebagian kecil perawat kurang patuh dalam penerapan prinsip tujuh benar pemberian obat sebanyak 4 orang $(8,70 \%)$.

\section{Hubungan Beban Kerja Perawat Dengan Penerapan Prinsip 7 Benar Pemberian Obat}

Tabel 6. Hasil Uji Korelasi Rank Spearman

\begin{tabular}{ccc}
\hline Variabel & Koefisien korelasi & Sig \\
\hline Beban Kerja Perawat ${ }^{\star}$ Prinsip7 benar Obat & $-0,454$ & 0,002 \\
\hline
\end{tabular}

Pada hasil uji Rank Spearman pada tabel 5 dapat dilihat bahwa nilai koefisien korelasi rank spearman bernilai negatif yaitu 0,454 . Arah negatif artinya semakin berat beban kerja perawat, maka penerapan Prinsip 7 Benar Obat akan semakin rendah. Berdasarkan hasil uji di atas dapat dilihat bahwa nilai Sig. (2-tailed) lebih kecil dari pada alpha yaitu 0,002 < 0,05) sehingga HO ditolak dengan kesimpulan terdapat hubungan antara berat beban kerja perawat dengan penerapan Prinsip 7 Benar Obat.

\section{PEMBAHASAN}

Beban Kerja perawat adalah keadaan dimana semua kegiatan yang dilakukan oleh perawat selama bekerja di unit pelayanan keperawatan (Marquis dan Houston, 2000). Berdasarkan hasil penelitian didapatkan data bahwa perawat yang bekerja di ruang rawat inap B, C, D, dan E di Rumah Sakit Wava Husada Kepanjen Malang, sebagian besar perawat memiliki beban kerja dalam kategori beban kerja sedang sebanyak 28 orang dan sebagian kecil perawat sebanyak 4 orang memiliki beban kerja berat.

Berdasarkan hasil analisa rekapitulasi jawaban dari kuesioner beban kerja yang dimodifikasi kembali oleh peneliti di Rumah Sakit Wava Husada Kepanjen pada ruang rawat inap $B, C, D$ dan $E$ bahwa perawat memiliki beban kerja lebih cenderung mempersepsikan bahwa ratio perawat dan klien tidak seimbang karena jumlah perawat lebih sedikit dari pada jumlah pasien yang dirawat sehingga perawat menjadi kelelahan saat bekerja, jumlah pasien yang banyak dengan kondisi yang dapat berubah sewaktuwaktu serta volume pekerjaan yang tinggi akan berpengaruh pada beban kerja perawat dalam pelaksanaan asuhan keperawatan. Dalam penelitian ini, terdapat sebagian besar perawat memiliki beban kerja sedang dan sebagian kecil perawat mempunyai beban kerja berat. Ini menandai adanya manajemen keperawatan yang kurang sesuai dengan Peraturan Menkes RI No.262/Menkes/Per/VII/1979 tentang ketenagaan RS yang menyebutkan bahwa Perbandingan jumlah tempat tidur dengan jumlah perawat harus seimbang.

Peneliti telah mengobservasi penerapan prinsip tujuh benar dalam pemberian obat di 4 ruangan di Rumah Sakit Wava Husada yaitu Benar pasien, dosis, benar obat, benar waktu, benar rute, benar indikasi dan benar dokumentasi. Penerapan prinsip benar obat ini sesuai dengan kebijakan yang ada di Rumah Sakit Wava Husada Kepanjen. Hasil observasi yang dilakukan oleh peneliti bahwa perawat dalam penerapan prinsip 7 benar dalam pemberian obat sebagian besar patuh dan sebagian kecil kurang patuh. Perawat yang dalam penerapan prinsip 7 benar pemberian obat kurang patuh dikarenakan perawat kurang menerapkan dalam hal benar indikasi obat. Mayoritas 
perawat kurang untuk penerapan prinsip benar indikasi dalam penerapan prinsip 7 benar obat di rumah sakit meliputi memberikan informasi kepada klien maupun kelurga, menjelaskan kegunaan obat dan menjelaskan efek samping obat kepada klien dan keluarga sehingga penerapan prinsip obat sangat kurang dalam pemberian asuhan keperawatan.

Berdasarkan hasil analisis statistik menggunakan uji korelasi spearman terdapat hubungan yang signifikan antara beban kerja perawat dengan penerapan prinsip 7 benar pemberian obat dengan nilai $p<0,05$. Hal ini didukung oleh nilai koefisien korelasi rank spearman bernilai negatif yaitu 0,454.

\section{KESIMPULAN}

Berdasarkan hasil penelitian didapatkan data bahwa :

1. Beban kerja perawat di Rumah Sakit Wava Husada Kepanjen Malang di dapatkan bahwa sebagian besar perawat memiliki beban kerja dalam kategori sedang

2. Sebagian besar perawat patuh dalam penerapan prinsip 7 benar pemberian obat pada pasien di ruang rawat inap.

3. Terdapat hubungan yang signifikan antara beban kerja perawat dengan penerapan prinsiip 7 benar pemberian obat

\section{SARAN}

Disarankan kepada perawat dapat memanajemen beban kerja dengan baik agar tidak berakibat pada pemberian asuhan keperawatan salah satunya pemberian obatobatan. Keamanan pemberian obat termasuk dalam sasaran kesalamatan pasien salah satu menjaga keamanan obat dengan penerapan prinsip 7 benar pemberian obat. Diharapkan

\section{DAFTAR PUSTAKA}

Agyemang, R.E.O. \& While, A. (2010) Medication Errors: Types,Causes and Impact on Nursing Practice, British Journal of Nursing, London

Arikunto, Suharsimi. 2013. Prosedur Penelitian Suatu Pendekatan Praktik. Jakarta:Rineka Cipta.

Armiyanti.Yunie, et al. 2007.Hubungan Tingkat Pendidikan dan Lama Kerja Perawat Dengan Penerapan Prinsip "Enam Benar" Dalam Pemberian obat di Ruang Rawat Inap RS Dr. Kariadi Semarang.Jurnal UNMUS 1 oktober 2007. Diambil 24 september, dari http://jurnalunimus.ac.id
Koefisien negatif menunjukkan semakin berat beban kerja perawat maka kepatuhan penerapan prinsip 7 benar obat akan semakin rendah.

Perawat saat melakukan tindakan penerapan prinsip benar obat tidak dapat melakukan dengan baik dikarenakan beban kerja yang terlalu berlebih yang dapat menimbulkan kesalahan perawat, situasi lingkungan dan pengaturan ketenangan serta manajemen yang ada berkaitan dengan individu seseorang yang memiliki bemacammacam karakteristik yang ada seperti umur, jenis kelamin, pendidikan, status perkawinan, dan lama masa kerja yang di kemukakan oleh Gibson (llyas, 2002).

perawat mengikuti kegiatan pelatihan yang diberikan untuk meningkatkan kualitas pelayanan keperawatan dan dapat meningkatkan keselamatan pasien serta perlu dilakukan supervisi oleh kepala ruangan serta monitoring untuk meningkatkan penerapan prinsip 7 benar pemberian obat.

Kepada institusi kesehatan diharapkan tetap memperhatikan tingginya pekerjaan tenaga kesehatan agar dapat memberikan asuhan keperawatan yang optimal dan berkualitas dengan memberikan reward kepada tenaga kesehatan yang memiliki pekerjaan yang baik, memberikan motivasi secara psikologi, diberikan pelatihan-pelatihan, dirotasi di ruangan lain, diberikan refreshing serta diberikan edukasi bagaimana cara untuk mengurangi beban kerja pada perawat, diharapkan dapat menurunkan beban kerja yang berdampak pada pemberian asuhan keperawatan salah satunya pemberian obatobatan yang menerapkan prinsip 7 benar dalam pemberian obat guna menurunkan kejadian tidak diharapkan (KTD).

Cohen, M.R. 1999. Medication Errors. The American Pharmaceutical Assosiation.

Carayon, P.\& Alvarado, C. 2007. Workload and patient safety among critical care nurse : systems engineering initiative for patient safety. Crit Care Nurs Clin North Am. 8(5), 121-129.

Hidayat, A. (2011). Pengantar konsep dasar keperawatan.Edisi 2. Jakarta: Salemba Medika.

Ilyas, Yaslis. 2002, Kinerja : Teori, Penilaian dan Penelitian, Pusat Kajian Ekonomi Kesehatan Fakultas Kesehatan Masyarakat Universitas Indonesia, Depok. 
Indracahyani A. 2010. Keselamatan Pemberian Medikasi, Jurnal Keperawatan Indonesia, Volume 13, No. 2, Juli 2010, 105-111

Joint Commission Resources. 2013. International patient safety goals. Diakses pada tanggal 01 Oktober 2017 dari www.jointcommissioninternational.org/Co mmon/PDFs/JCl\%20Accreditation/Interna tional Patient Safety Goals Feb2012.pd $\mathrm{f}$

Leape, L.L, Bates DW, Cullen DJ, et al. 1995. System Analysis of Adverse Drug Events.JAMA ; 274:29-34

Manuaba, A. 2000.Ergonomi Kesehatan Keselamatan Kerja. Dalam Wygnyosoebroto s \& Wiranto, S.E:Eds. Processing Seminar Nasional Ergonomi PT. Guna Widya Surabaya.

Munandar, A.S. 2001. Stress dan Keselamatan Kerja Psikologi Industri dan Organisasi. Penerbit Universitas Indonesia.Munandar, A.S. 2001. Stress dan Keselamatan Kerja Psikologi Industri dan Organisasi. Penerbit Universitas Indonesia.

Munandar.2001. Psikologis Industri dan Organisasi. Depok: Penerbit Universitas Indonesia (UI Press).

Munandar, 2005.Psikologis Industri dan Organisasi, UI-Press: Jakarta.

Notoadmodjo, Soekidjo. 2002. Metodologi Penelitian Kesehatan. Rineka Cipta : Jakarta.

Nursalam. 2010. Konsep dan penerapan metodelogi penelitian ilmu keperawatan. Jakarta: Salemba medika

Nursalam, 2015.Manajemen Keperawatan. Jakarta: Salemba Medika.

Pitaloka, Diah. 2010. Pengaruh Kondisi Kerja dan Beban Kerja Terhadap Stres Kerja Perawat di RSU Kabanjahe Kab. Karo Tahun 2010.

Potter, P. A. \& Perry, A.G. 2005. Fundamental Of Nursing : Cocepts, Process, And Practice. (4thEd). Philadelphia : Mosby. Alih Bahasa Renata Komalasari. EGC: Jakarta

Prastito, Arif. 2004. Cara Mudah Mengatasi Maslah Statistik dan Rancangan Percobaan dengan SPSS 12. Elex Media Komputindo: Jakarta
Prawitasari, S. 2008. Laporan kegiatan residensi kepemimpinan dan manajemen keperawatan di RS Husada Jakarta.Jakarta : FIKUI.

Samba.S, 2000.Pengantar Kepemimpian dan Manajemen Keperawatan Untuk Perawatan Klinis.Jakarta: Buku Kedokteran, EGC.

Suyanto. 2008. Mengenal kepemimpinan dan manajemen keperawatan di rumah sakit.Jogjakarta : Mitra Cendikia Press

Swansbrug.RC, Swansbrug RJ, 1999.Introductory manajement And Leadership For Nurse. 2 an Edition. Jakarta: Torono And Burtiet publisher

Tambayong Jan.(2001). Farmakologi Untuk Keperawatan. Penerbit Widya Medika, Jakarta.

Tambayong. 2002. Anatomi Fisiologi untuk Keperawatan.Editor Monica Ester, Jakarta : EGC.

Tajudin Rusmi S, Sudirman Indrianty, Maidin alimin (2012). Faktor Penyebab Medication Error Di Instalasi Rawat Darurat. Jurnal Manajemen Pelayanan Kesehatan, Vol. 5, No. 4 Desember 2014

Wardana, R Suryani, M. Sayono. 2013. Hubungan karakteristik perawat dengan penerapan prinsip 6 benar dalam pemberian obat di ruang rawat inapRSUD Dr. H. SOEWONDO Kendal. Jurnal IImu Keperawatan dan Kebidanan, vol 1, No. 4.

Widodo, 2010. Perbedaan tingkat stres kerja antara perawat kritis dan perawat gawat darurat di RSUD Dr Moewardi Surakarta.Skripsi. (tidak diterbitkan). Surakarta: Fakultas IImu Kesehatan Universitas Muhammadiyah Surakarta

World Health Organization, 2012. Medication Administration, Washtenaw Community College Worlforce Development 